\title{
PENGARUH PENGETAHUAN TERHADAP KEPATUHAN WAJIB PAJAK PERORANGAN DI KOTA SEMARANG
}

\author{
Anita Damajanti, SE.Akt Msi
}

\begin{abstract}
ABSTRAK
Self assessment system merupakan sistem pemungutan pajak yang memberi kepercayaan, tanggung jawab kepada wajib pajak untuk menghitung, menyetor, dan melporkan sendiri besarnya pajak yang terutang. Di Indonesia self assessment system telah dilaksanakan sejak tahun 1984, tetapi tingkat kepatuhan wajib pajak di Indonesia masih lebih rendah dibandingkan Malaysia yang baru melaksanakan self assessment system sejak tahun 2001. Menurut Santoso Brotodihardjo (1990) self assessment system dapat berhasil baik jika masyarakat pembayar pajak memiliki pengetahuan dan disiplin pajak yang tinggi (tax conscousness). Menurut Palil (2010) spirit dari self assessment system adalah mendidik wajib pajak dan membuat mereka peduli dengan kewajiban perpajakan mereka (Palil, Moh. Risal, 2010). Oleh karena itu wajib pajak harus memiliki pengetahuan untuk memahami peraturan perpajakan.

Penelitian ini bertujuan menguji secara empiris pengaruh pengetahuan wajib pajak terhadap kepatuhan dalam menjalankan peraturan perpajakan. Pelaksanaan self assessment system dalam pemungutan pajak menuntut wajib pajak untuk dapat menghitung sendiri, menyetor dan melaporkan pajak pajak terutang. Oleh karena itu variabel yang digunakan dalam penelitian ini terdiri dari pengetahuan wajib pajak dalam perhitungan, pengetahuan penyetoran dan pengetahuan pelaporan pajak. Populasi penelitian ini yaitu wajib pajak perorangan non karyawan di kota Semarang. Sampel dipilih dengan metode convenience sampling. Logistic regression digunakan untuk menguji hipotesis pengaruh pengetahuan terhadap kepatuhan wajib pajak.

Berdasarkan 100 kuesioner yang diberikan kepada responden diperoleh sebanyak 75 kuesioner yang dapat diolah. Hasil pengujian kualitas data variabel pengetahuan pelaporan, pengetahuan pembayaran pajak dan pengetahuan penghitungan pajak menunjukkan hasil yang valid dan reliabel. Namun demikian hasil uji hipotesis menunjukkan tidak ada pengaruh signifikan antara variabel pengetahuan pelaporan, pengetahuan pembayaran, dan pengetahuan penghitungan terhadap kepatuhan wajib pajak. Hasil ini berbeda dengan penelitian-penelitian sebelumnya yang menunjukkan adanya pengaruh signikan pengetahuan terhadap kepatuhan wajib pajak. Nilai Nagelkerke $\mathrm{R}$ Square sebesar 0,15 menunjukkan kemampuan variabel independen untuk mempediksi variabel dependennya yaitu kepatuhan sebesar 15\%. Penelitian selanjutnya diharapkan menambah variabel lain yang diprediksikan dapat mempengaruhi kepatuhan wajib pajak misalnya kondisi keuangan wajib pajak.
\end{abstract}

Kata kunci : pengetahuan, kepatuhan, wajib pajak perorangan non karyawan

\section{PENDAHULUAN}

Self assessment system sebagai sistem penetapan pajak di Indonesia telah diterapkan sejak tahun 1983, dimana sebelumnya diberlakukan official assessment system. self assessment system merupakan sistem pemungutan pajak yang memberi kepercayaan, tanggung jawab kepada wajib pajak untuk menghitung, menyetor, dan melporkan sendiri besarnya pajak yang terutang. Official assessment system merupakan sistem pemungutan yang 
memberi wewenang kepada fiskus untuk menentukan besarnya pajak terutang. Self assessment system memberi wewenang kepada wajib pajak untuk menentukan besarnya pajak terutang. self assessment system system memerlukan kompetensi, kejujuran, kapabilitas, dan kesiapan wajib pajak dalam memperhitungkan beban pajak terutang. Oleh karena itu diperlukan pengetahuan wajib pajak dalam pelaksanaan self assessment system. Ketidakpahaman wajib pajak dapat mengakibatkan ketidak akuratan dalam menghitung pajak penghasilan terutang. (Palil, 2010). Di Indonesia self assessment system telah dilaksanakan sejak tahun 1984, tetapi tingkat kepatuhan wajib pajak di Indonesia masih lebih rendah dibandingkan di Negara lain bahkan dengan Malaysia yang baru melaksanakan self assessment system sejak tahun 2001.

Salah satu kendala dalam menjalankan self assessment system adalah wajib pajak secara sukarela mematuhi peraturan perpajakan. Berdasarkan penelitian sebelumnya dalam self assessment system wajib pajak cenderung kurang patuh dibandingkan dengan sistem direct assessment. Hal ini dapat terjadi karena ketidakpatuhan yang tidak disengaja khususnya pada masa-masa awal pengenalan terhadap sistem, dan tidak terbiasa dengan sistem, atau keterbatasan pengetahuan tentang issue-issue perpajakan. (Palil, 2010)

Hasil penelitian Tarjo, 2006 di Bangkalan, menunjukkan $69,6 \%$ wajib pajak perorangan tidak mengetahui tarif pajak yang berlaku, dan $78,6 \%$ tidak mengetahui perubahan perundangundangan khususnya pajak penghasilan. Sebanyak $57,1 \%$ wajib pajak memakai jasa fiskus ataupun kosultan untuk menghitung pajak terutang, hanya $42,9 \%$ wajib pajak yang menghitung sendiri pajak terutangnya.Hasil penilitian ini menunjukkan tidak tercapainya tujuan self assessment system. Wajib pajak yang melakukan kesalahan dalam menghitung pajak terutang adalah sebesar $53,6 \%$. Hasil penelitian ini menunjukkan rendahnya pengetahuan wajib pajak terhadap peraturan perpajakaan.

Rendahnya

pemahaman masyarakat menjadi hambatan untuk melaksanakan peraturan perpajakan. Menurut Santoso Brotodihardjo (1990) self assessment system dapat berhasil baik jika masyarakat pembayar pajak memiliki pengetahuan dan disiplin pajak yang tinggi (tax conscousness). Menurut Palil (2010) spirit dari self assessment system adalah mendidik wajib pajak dan membuat mereka peduli dengan kewajiban perpajakan mereka (Palil, Moh. Risal, 2010). Oleh karena itu wajib pajak harus memiliki pengetahuan untuk memahami peraturan perpajakan.

Menurut Direktur Jenderal Pajak Fuad Rahmany terdapat 40 juta warga telah mampu membayar pajak tetapi belum membayar. Potensinya diperkirakan minimal Rp.150 triliun (Kompas, 07/03/2014). Potensi pajak perseorangan yang masih besar bisa memberikan pemasukan bagi negara untuk mendukung pemerataan pendapatan.

Kepala pusat studi ekonomi dan kebijakan publik Universitas Gajah Mada Yogyakarta A Tony Prasetiantono menyatakan kesenjangan ekonomi yang kian besar bisa dikurangi dengan optimalisasi penerimaan pajak. Menurut dia, pemerintah belum menarik pajak perseorangan dengan baik. Jika pajak penghasilan dapat ditarik secara efektif termasuk meminimalkan kebocoran, ada potensi tambahan pajak sekitar Rp 200 triliun. (Kompas, 07/03/2014).

Pelaksanaan self assessment system dalam pemungutan pajak di 
Indonesia akan berhasil baik jika wajib pajak memiliki pengetahuan yang memadahi tentang peraturan perpajakan. Rendahnya tingkat kepatuhan wajib pajak perorangan saat ini kemungkinan karena kurang pengetahuan perpajakan. Menurut Palil (2010) banyak faktor yang mempengaruhi kepatuhan wajib pajak, tetapi pengetahuan merupakan faktor utama khususnya dalam pelaksanaan self assessment system.

Oleh karena itu pertanyaan dalam penelitian ini adalah :

1. Bagaimana tingkat pengetahuan wajib pajak perorangan kota Semarang?

2. Bagaimana pengaruh pengetahuan wajib pajak perorangan dalam melaksanakan peraturan perpajakan?

\section{TUJUAN PENELITIAN}

1. Memberikan gambaran tingkat pengetahuan wajib pajak di kota Semarang tentang peraturan pajak.

2. Menguji secara empiris pengaruh pengetahuan wajib pajak terhadap kepatuhan dalam menjalankan peraturan perpajakan wajib pajak perseorangan.

\section{MANFAAT PENELITIAN}

Penelitian ini diharapkan dapat memberi gambaran tingkat pengetahuan wajib pajak dalam memahami peraturan Undang-Undang, sehingga diharapkan dapat memberi masukan bagi Pemerintah propinsi maupun Kanwil DJP Jateng mengenai bentuk-bentuk sosialisasi yang sesuai bagi masyarakat.

\section{TINJAUAN PUSTAKA}

\section{Definisi Pajak}

Definisi pajak menurut UndangUndang No.28 tahun 2007 tentang
Ketentuan Umum dan tata Cara Perpajakan adalah kontribusi wajib kepada negara yang terutang oleh orang pribadi atau badan yang bersifat memaksa berdasarkan undang-undang, dengan tidak mendapatkan imbalan secara langsung dan digunakan untuk keperluan negara bagi sebesar-besarnya kemakmuran rakyat.

Sistem Pemungutan Pajak di Indonesia

Sistem pemungutan pajak dikenal ada 3 sistem yaitu : (Mardiasmo, 1995.,h.8-9)

\section{Official Assessment System}

Adalah suatu sistem pemungutan yang memberi wewenang kepada pemerintah (fiskus) untuk menentukan besarnya pajak yang terutang oleh wajib pajak. Ciri-cirinya :

- wewenang untuk menentukan besarnya pajak terutang ada pada fiskus

- wajib pajak bersifat pasif

- utang pajak timbul setelah dikeluarkan surat ketetapan pajak oleh fiskus.

\section{Self Assessment System}

Adalah suatu sistem pemungutan pajak yang memberi wewenang kepada wajib pajak untuk menentukan sendiri besarnya pajak yang terutang. Ciricirinya

- wewenang untuk menentukan besarnya pajak terutang ada pada wajib pajak sendiri.

- wajib pajak aktif, mulai dari menghitung, menyetor dan melaporkan sendiri pajak yang terutang.

- fiskus tidak ikut campur dan hanya mengawasi.

Di Indonesia self assessment system diberlakukan dalam pemungutan pajak pusat yaitu PPh dan PPN-PPnBM. 
Wajib pajak diberi kewenangan untuk menghitung sendiri serta melaporkan jumlah penghasilan dan jumlah pajak terutang. Menurut Santoso Brotodihardjo (1994) tata cara ini hanya dapat berhasil baik bilamana masyarakat pembayar pajak sendiri memiliki pengetahuan dan disiplin pajak yang tinggi (tax conscousness).

\section{Witholding System}

Adalah suatu sistem pemungutan pajak yang memberi wewenang kepada pihak ketiga (bukan fiskus dan bukan wajib pajak yang bersangkutan) untuk menentukan besarnya pajak yang terutang oleh wajib pajak. Ciri-cirinya : wewenang menentukan besarnya pajak yang terutang ada pada pihak ketiga, pihak selain fiskus dan wajib pajak.

Menurut Prof Adriani yang dikutip oleh Santoso Brotodihardjo, (1990, h.6465 ) cara memungut pajak dibagi menjadi golongan :

a. Wajib pajak menentukan sendiri jumlah pajak yang terutang sesuai dengan ketentuan undang-undang perpajakan. Fiskus membatasi diri pada pengawasan. Cara ini dikenal juga dengan istilah self assessment system. Dalam tata cara self assessment system kegiatan wajib pajak diberi kewenangan untuk:

- menghitung sendiri besarnya pendapatan/kekayaan/laba.

- menghitung sendiri besarnya pajak pendapatan/kekayaan/ perseroan yang terutang dan menyetorkannya ke kas negara.

b. Ada kerja sama antara wajib pajak dan fiskus, (tetapi kata terakhir ada pada fiskus) dalam bentuk ;

- pemberitahuan sederhana dari wajib pajak
- pemberitahuan yang lengkap dari wajib pajak.

c. Fiskus menentukan sendiri (di luar wajib pajak) jumlah wajib pajak yang terutang.

d.

Hambatan Pemungutan Pajak

Hambatan terhadap pemungutan pajak dikelompokkan sebagai berikut : (Mardiasmo, 1998, h. 9-10)

1. Perlawanan pasif

Masyarakat enggan (pasif) membayar pajak, yang dapat disebabkan antara lain:

a. Perkembangan intelektual dan moral masyarakat.

b. Sistem perpajakan yang (mungkin) sulit dipahami masyarakat.

c. Sistem kontrol tidak dapat dilakukan dengan baik.

Menurut Santoso Brotodihardjo (1990), perlawanan pasif terdiri dari hambatan-hambatan yang mempersulit pemungutan pajak dan yang erat hubungannya dengan struktur ekonomi suatu negara, perkembangan intelektual dan moral penduduk, dan dengan teknik pemungutan pajak itu sendiri. Contoh pajak penghasilan yang biasanya telah terintegrasi dalam suatu sistem ekonomi dengan sifatnya yang industrial, pada hakikatnya kurang tepat bagi negara agraris karena petani umumnya tidak memahami pembukuan. Di beberapa negara perlawanan pasif terhadap pajak langsung lebih kuat jika dibandingkan dengan pajak tak langsung.

\section{Perlawanan Aktif}

Perlawanan aktif meliputi semua usaha dan perbuatan yang secara langsung ditujukan kepada fiskus dengan tujuan untuk menghindari pajak. Bentuknya antara lain : 
a. tax avoidance, usaha meringankan beban pajak dengan cara yang tidak melanggar undang-undang.

b. tax evasion, usaha meringankan beban pajak dengan cara yang melanggar undang-undang (menggelapkan pajak).

\section{Kepatuhan Wajib Pajak}

Kepatuahan wajib pajak (tax compliance) didefinisikan oleh beberapa peneliti yang dikutip oleh Palil (2010) sebagai berikut :

1. Andreoni, Erard, and Feinstein :

Kepatuhan wajib pajak adalah kemauan wajib pajak untuk mematuhi peraturan perpajakan dalam rangka mencapai keseimbangan perekonomian di suatu negara.

2. Kirchler :

Kepatuhan wajib pajak adalah istilah umum untuk menggambarkan kemauan wajib pajak untuk membayar pajak.

3. Song and Yarbrough :

Kepatuhan wajib pajak adalah kemampuan dan kemauan untuk mematuhi peraturan perpajakan yang ditentukan oleh etika, hukum, lingkungan dan faktor situasional lainnya.

4. IRS, 2009; ATO, 2009; IRB, 2009 :

Kepatuhan wajib pajak adalah kemampuan dan kemauan untuk mematuhi peraturan pajak, melaporkan penghasilan diterima dalam satu tahun dengan benar, dan membayar jumlah yang benar secara tepat waktu.

5. Alm (1991) and Jackson and Milliron (1986) :

Kepatuhan pajak adalah pelaporan seluruh penghasilan dan pembayaran seluruh pajak terutang sesuai ketentuan hukum yang berlaku.

6. (Singh, 2003)

Kepatuhan pajak adalah tindkan seseorang untuk melaporkan semua penghasilan kena pajak secara akurat, dan membayar semua hutang pajak pada waktu yang ditentukan tanpa harus menunggu tindak lanjut dari otoritas.

7. (Chow, 2004; Harris, 1989) :

Kepatuhan pajak dipisahkan menjadi dua perspektif, yaitu kepatuhan dalam hal administrasi dan kepatuhan dalam hal kebenaran (akurat) penghitungan pajak penghasilan.

Definisi kepatuhan pajak di Indonesia :

Di Indonesia kriteria wajib pajak patuh diatur di Peraturan Menteri Keuangan Republik Indonesia Nomor 192/PMK. 03/2007 tentang Tata cara penetapan Wajib Pajak dengan kriteria tertentu dalam rangka penembalian Pendahuluan Kelenihan Pembayaran Pajak. Peraturan tersebut menyatakan bahwa wajib pajak yang memenuhi kriteria tertentu disebut sebagai wajib pajak patuh dan berhak mengajukan permohonan pengembalian pendahuluan terhadap kelebihan pembayaran pajak.

Kriteria tersebut adalah sebagai berikut :

a. penyampaian SPT Tahunan tepat waktu dalam 3 (tiga) tahun terakhir.

b. Penyampaian SPT Masa yang terlambat dalam tahun terakhir untuk masa pajak Januari sampai November tidak lebih dari 3 (tiga) masa pajak untuk setiap jenis pajak, tidak berturt-turut dan telah disampaikan tidak lewat dari batas waktu penyampaian SPT masa pajak berikutnya.

c. Tidak mempunyai tunggakan pajak untuk semua jenis pajak, kecuali tunggakan pajak yang telah memperoleh izin mengangsur atau menunda pembayaran pajak.

Tidak mempunyai tunggakan pajak menurut kriteria ini adalah keadaan 
pada tanggal 31 Desember tahun sebelum penetapan sebagai wajib pajak patuh dan tidak termasuk utang pajak yang belum melewati batas akhir pelunasan.

d. Laporan keuangan diaudit oleh akuntan publik atau lembaga pengawasan keuangan pemerintah dengan pendapat wajar tanpa pengecualian selama 3 (tiga) tahun berturut-turut; dan tidak pernah dipidana karena melakukan tindak pidana di bidang perpajakan berdasarkan putusan pengadilan yang telah mempunyai kekuatan hukum tetap dalam jangka waktu 5 (lima) tahun terakhir. Laporan keuangan tersebut harus disusun dalam bentuk panjang (long form report) dan menyajikan rekonsiliasi laba rugi komersial dan fiskal bagi wajib pajak yang wajib menyampaikan SPT Tahunan. Pendapat akuntan atas Laporan Keuangan yang diaudit oleh Akuntan Publik ditandatangani oleh Akuntan Publik yang tidak sedang dalam pembinaan lembaga pemerintah pengawas akuntan publik.

Natrah Saad (2014) meneliti tingkat pengetahuan pajak dan persepsi wajib pajak terhadap kompleksitas sistem pemungutan pajak penghasilan, serta alasan yang mendasari untuk ketidakpatuhan wajib pajak. Data dikumpulkan melalui wawancara telepon dengan tiga puluh peserta, dan dianalisis menggunakan analisis tematik. Hasil menunjukkan bahwa wajib pajak tidak memiliki pengetahuan teknis yang memadahi dan menganggap sistem pajak rumit. Pengetahuan pajak dan kompleksitas pemungutan pajak dipandang sebagai faktor yang berkontribusi terhadap perilaku ketidakpatuhan antara pembayar pajak.

\section{Pengetahuan Wajib Pajak}

1. Pengetahuan adalah berbagai gejala yang ditemui dan diperoleh manusia melalui pengamatan akal. Pengetahuan muncul ketika seseorang menggunakan akal budinya untuk mengenali benda atau kejadian tertentu yang belum pernah dilihat atau dirasakan sebelumnya.

2. Pengetahuan adalah informasi yang telah dikombinasikan dengan pemahaman dan potensi untuk menindaki; yang melekat di benak seseorang. Pada umumnya, pengetahuan memiliki kemampuan prediktif terhadap sesuatu sebagai hasil pengenalan atas suatu pola. Manakala informasi dan data sekedar berkemampuan untuk menginformasikan atau bahkan menimbulkan kebingungan, maka pengetahuan berkemampuan untuk mengarahkan tindakan. Ini lah yang disebut potensi untuk menindaki.

Jenis Pengetahuan dibagi sebagai berikut :

1. Pengetahuan Implisit

Pengetahuan implisit adalah pengetahuan yang masih tertanam dalam bentuk pengalaman seseorang dan berisi faktor-faktor yang tidak bersifat nyata seperti keyakinan pribadi, perspektif, dan prinsip. Contoh : kemampuan mengendara sepeda. Seseorang yang memiliki pengetahuan implisit biasanya tidak menyadari bahwa dia sebenarnya memilikinya dan juga bagaimana pengetahuan itu bisa menguntungkan orang lain. Pengetahuan implisit seringkali berisi kebiasaan dan budaya yang tidak disadari.

2. Pengetahuan Eksplisit

Pengetahuan eksplisit adalah pengetahuan yang telah didokumentasikan atau disimpan dalam wujud nyata berupa media atau semacamnya. 
3. Pengetahuan Empiris

Pengetahuan yang lebih menekankan pengamatan dan pengalaman inderawi dikenal sebagai pengetahuan empiris atau pengetahuan aposteriori. Pengetahuan ini bisa didapatkan dengan melakukan pengamatan yang dilakukan secara empiris dan rasional. Pengetahuan empiris tersebut dapat berkembang menjadi pengetahuan deskriptif bila sesorang dapat melukiskan dan menggambarkan segala ciri, sifat, dan gejala yang ada pada objek empiris tersebut. Pengetahuan empiris tersebut juga bisa didapatkan melalui pengalaman pribadi manusia yang terjadi berulangkali Misalnya, seseorang yang sering dipilih untuk memimpin organisasi dengan sendirinya akan mendapatkan pengetahuan tentang manajemen organisasi.

4. Pengetahuan rasionalisme

Pengetahuan rasionalisme adalah pengetahuan yang diperoleh melalui akal budi. Rasionalisme lebih menekankan pengetahuan yang bersifat apriori; tidak menekankan pada pengalaman. Misalnya pada pengetahuan tentang matematika, hasil $1+1=2$ bukan didapatkan melalui pengalaman atau pengamatan empiris, melainkan melalui sebuah pemikiran logis akal budi.

Pengetahuan wajib pajak tentang peraturan perpajakan diperoleh melalui pendidikan formal, pelatihan, atau sosialisasi. Oleh karena itu dapat disimpulkan bahwa pengetahuan tersebut adalah pengetahuan rasional.

Menurut Santoso Brotodihardjo (1994) tata cara ini hanya dapat berhasil baik bilamana masyarakat pembayar pajak sendiri memiliki pengetahuan dan disiplin pajak yang tinggi (tax conscousness).

Widayati (2010) mengelompokkan pengetahuan perpajakan terdiri dari pengetahuan tentang kepemilikan NPWP, pengetahuan dan pemahaman mengenai hak dan kewajiban sebagai wajib pajak, pengetahuan dan pemahaman mengenai sanksi perpajakan, pengetahuan dan pemahaman mengenai PTKP, PKP dan tarif pajak.

\section{Pengaruh Pengetahuan terhadap Kemauan membayar Pajak}

Pengetahuan adalah hasil kerja fikir ( penalaran ) yang merubah tidak tahu menjadi tahu dan menghilangkan keraguan terhadap suatu perkara. Terdapat beberapa indikator bahwa wajib pajak mengetahui dan memahami peraturan perpajakan. Pertama, kepemilikan NPWP. Setiap wajib pajka yang memiliki penghasilan wajib untuk mendaftarkan diri untuk memperoleh NPWP sebagai salah satu sarana untuk pengadministrasian pajak. Kedua, pengetahuan dan pemahaman mengenai hak dan kewajiban sebagai wajib pajak. Apabila wajib pajak telah mengetahui dan memahami kewajibannya sebagai wajib pajak, maka mereka akan melakukannya, salah satunya adalah membayar pajak. Ketiga, pengetahuan dan pemahaman mengenai sanksi perpajakan. Semakin tahu dan paham wajib pajak terhadap peraturan perpajakan, maka semakin tahu dan paham pula wajib pajak terhadap sanksi yang akan diterima bila melalaikan kewajiban perpajakan mereka. Hal ini tentu akan mendorong setiap wajib pajak yang taat akan menjalankan kewajibannnya dengan baik. Keempat, pengetahuan dan pemahaman mengenai PTKP,PKP dan tarif pajak. Dengan mengetahui dan memahami mengenai tarif pajak yang berlaku, maka akan dapat mendorong wajib pajak untuk dapat menghitung kewajiban pajak sendiri secara benar. Kelima adalah 
wajib pajak mengetahui dan memahami peraturan perpajakan melalui sosialisasi yang dilakukan oleh KPP dan yang keenam bahwa wajib pajak mengetahui dan memahami peraturan pajak melalui training perpajakan yang mereka ikuti.

Menurut Santoso Brotodihardjo (1994) self assessment system dapat berhasil baik bilamana masyarakat pembayar memiliki pengetahuan dan disiplin pajak yang tinggi (tax conscousness). Self assessment system wajib pajak harus mampu menghitung, menyetor dan melaporkan pajak terutang. Oleh karena itu dalam penelitian ini pengetahuan pajak dikelompokkan menjadi tiga variabel yaitu : pengetahuan untuk menghitung pajak, pengetahuan tata cara pembayaran pajak dan pengetahuan tata cara pelaporan pajak.

Penelitian yang dilakukan oleh Eriksen dan Fallan yang dikutip oleh Palil (2010) menyatakan bahwa pengetahuan perpajakan berhubungan dengan sikap terhadap perpajakan dan perilaku wajib pajak dapat diperbaiki dengan pemahaman lebih baik tentang hukum pajak. Menurut Palil (2010) banyak faktor yang mempengaruhi kepatuhan wajib pajak, tetapi pengetahuan adalah adalah pengaruh utama khususnya di Self assessment system. Hasil Penelitian Palil (2010) di Malaysia menyatakan bahwa pengetahuan tentang sanksi dan denda, pengetahuan tentang hak dan kewajiban wajib pajak, pengetahuan tentang penghasilan yang dikenakan pajak dan penghasilan yang tidak dikenakan pajak berpengaruh signifikan terhadap kepatuhan wajib pajak.

Penelitian Saad, (2013) di Malaysia menunjukkan responden tidak memiliki pengetahuan teknis yang cukup tentang pajak dan mempersepsikan kompleknya sistem perpajakan. Hal ini memberikan kontribusi terhadap ketidakpatuhan wajib pajak di Malaysia. Menurut Nirawan Adiasa (2013) pemahaman wajib pajak terhadap peraturan perpajakan adalah cara wajib pajak dalam memahami peraturan perpajakan yang telah ada (Hardiningsih, 2011). Fenomena yang terjadi saat ini adalah masih banyaknya wajib pajak yang belum memahami akan peraturan pajak. Penelitian Nirawan Adiasa (2013) terhadap wajib pajak orang pribadi di wilayah Semarang Barat menunjukan bahwa pemahaman tentang peraturan perpajakan berpengaruh terhadap kepatuhan wajib pajak.

Menurut banu Witono (2008), dalam kaitannya dengan Wajib Pajak, kepatuhan dapat didefinisikan sebagai perilaku Wajib Pajak dalam memenuhi kewajiban perpajakannya sesuai dengan peraturan yang berlaku. Perilaku tersebut sangat dipengaruhi oleh motivasi. Biasanya motivasi akan berpengaruh terhadap intensitas perilaku (termotivasi, tanpa motivasi, dan apatis), dan kesesuaian dengan tujuan perilaku (efektif, tidak efektif) (Budiatmanto, 1999: 48). Sedangkan Luigi Alberto Fronzoni (1999) menyatakan bahwa Kepatuhan dalam hukum pajak memiliki arti umum sebagai (1) melaporkan secara benar dasar pajak, (2) memperhitungkan secara benar kewajiban, (3) tepat waktu dalam pengembalian, (4) tepat waktu membayar jumlah dihitung. Dan Alm (1991) mendefinisikan kepatuhan sebagai pelaporan semua pendapatan dan pembayaran pajak secara keseluruhan yang sesuai dengan aplikasi hukum, peraturan dan keputusan hakim (dalam Palil 2005).

Salah satu unsur yang bisa ditekankan oleh aparat dalam meningkatkan kesadaran dan kepatuhan pajak adalah dengan cara menyosialisasikan peraturan 
pajak baik itu melalui penyuluhan, seruan moral baik dengan media billboard, baliho, maupun membuka situs peraturan pajak yang setiap saat bisa diakses Wajib Pajak. Sehingga dengan adanya sosialisasi tersebut pengetahuan Wajib Pajak terhadap kewajiban perpajakannya bertambah tinggi. Pengetahuan tentang peraturan perpajakan penting untuk menumbuhkan perilaku patuh, karena bagaimana mungkin Wajib Pajak disuruh patuh apabila mereka tidak mengetahui bagaimana peraturan perpajakan, artinya bagaimana Wajib Pajak disuruh untuk menyerahkan SPT tepat waktu jika mereka tidak tahu kapan waktu jatuh tempo penyerahan SPT.
Berdasarkan kajian teoritis dan hasil penelitian sebelumnya hipotesis penelitian ini dirumuskan sebagai berikut :

H1 : pengetahuan mengenai penghitungan pajak berpengaruh signifikan terhadap kepatuhan wajib pajak perorangan.

$\mathrm{H} 2$ : pengetahuan mengenai tata cara pembayaran pajak berpengaruh signifikan terhadap kepatuhan wajib pajak perorangan

$\mathrm{H} 3$ : pengetahuan mengenai tata cara pelaporan pajak berpengaruh signifikan terhadap kepatuhan wajib pajak perorangan.

Hipotesis tersebut digambarkan dalam penelitian sebagai berikut :

Gambar 1

Kerangka Pikir Teoritis

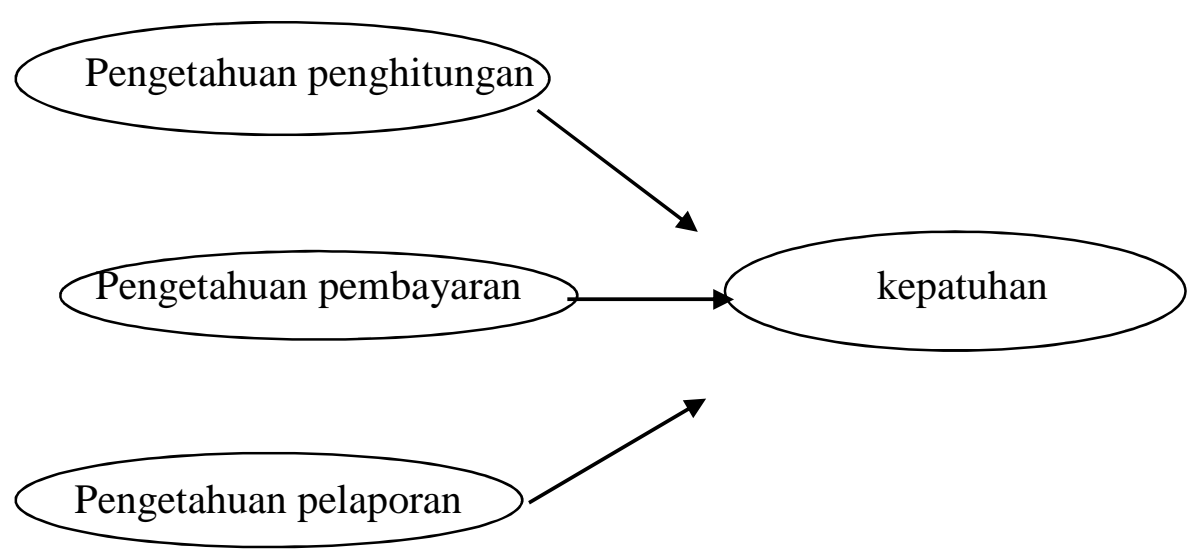

\section{Variabel dan Definisi Operasional}

\section{Pengetahuan Pajak}

Pelaksanaan self assessment system dalam pemungutan pajak menuntut wajib pajak untuk dapat menghitung sendiri, menyetor dan melaporkan pajak pajak terutang. Oleh karena itu variabel pengetahuan pajak dalam penelitian terdiri dari pengetahuan wajib pajak dalam perhitungan, penyetoran dan pelaporan pajak terutang. Indikator tersebut mengacu pada lampiran Peraturan Direktur Jenderal 
Pajak Nomor : PER-34/PJ/2010, Peraturan Pemerintah No.46 tahun 2013, dan pasal 17 ayat (1) UU No.36 tahun 2008 dan penjelasannya. Berdasarkan peraturan tersebut indikator variabel adalah sebagai berikut :

1. Indikator Pengetahuan penghitungan pajak

a. Wajib Pajak yang berhak menggunakan Norma Penghitungan Penghasilan Neto adalah yang penerimaan brutonya kurang dari Rp4.800.000.000,- setahun, dan telah memberitahukan kepada KPP dalam jangka waktu 3 (tiga) bulan pertama dari Tahun Pajak yang bersangkutan.

b. Wajib Pajak perorangan yang memperoleh penghasilan bruto tidak lebih dari Rp.4,8 Miliar dikenakan $\mathrm{PPh}$ final sebesar $1 \%$ dari penghasilan bruto sesuai PP 46 tahun 2013.

c. Wajib pajak yang memperoleh penghasilan dari usaha jasa pekerjaan bebas dikecualikan dari pengenaan PPh final sesuai PP 46 tahun 2013.

d. Jumlah penghasilan yang tidak dikenakan pajak (PTKP) wajib pajak perorangan adalah Rp. 24.300.000,-

e. Wajib pajak berhak mengkompensasi-kan kerugian yang diperoleh 5 tahun sebelumnya berturut-turut.

f. Tambahan PTKP diberikan untuk status kawin, isteri yang pemajakannya digabung dengan suami, dan tanggungan maksimal 3 orang, masing-masing sebesar Rp.2.025.000,- setahun.

- Jika penghasilan kena pajak yang diperoleh setahun sebesar Rp. 350.000.000,- maka pph terutang sebesar ( 5\% x Rp.50.000.000,- + Rp.10\% x Rp.200.000.000,- + 15\% x Rp.100.000.000,-)

- gaji/honorarium/imbalan lainnya, tunjangan hari tua dan tunjangan lainnya, premi asuransi yang dibayar pemberi kerja adalah jenis penghasilan yang dikenakan pajak

- Untuk menghitung penghasilan neto dalam negeri sehubungan dengan pekerjaan adalah penghasilan bruto dikurangi biaya jabatan, dan iuran pensiun yang terikat pada gaji

- Biaya pensiun adalah biaya untuk mendapatkan, menagih, dan memelihara penghasilan yang diterima dari pemberi kerja oleh setiap pensiunan tanpa memandang kedudukan atau jabatan yang besarnya 5\% dari penghasilan bruto, dengan jumlah maksimal Rp2.400.000,- setahun atau Rp200.000 sebulan yang dihitung menurut banyaknya bulan perolehan dalam tahun yang bersangkutan.

- bunga deposito, tabungan, hadiah undian, sewa tanah/bangunan, pengalihan hak atas tanah/ bangunan dikenakan $\mathrm{PPh}$ final.

2. Indikator Pengetahuan pembayaran pajak:

- Kekurangan pembayaran pajak yang terutang berdasarkan SPT Tahunan harus dibayar lunas sebelum SPT Tahunan disampaikan

- Pembayaran yang dilakukan setelah tanggal jatuh tempo dikenai bunga $2 \%$ per bulan

- Dalam sanksi administrasi berupa bunga, bagian dari bulan dihitung 1 bulan penuh dan diterapkan mulai tanggal jatuh tempo pembayaran sampai tanggal pembayaran

- Direktur Jenderal Pajak dapat memberikan persetujuan untuk 
mengangsur atau menunda pembayaran pajak terutang berdasarkan SPT Tahunan, paling lama 12 bulan.

3. Indikator Pengetahuan pelaporan pajak

- Wajib pajak perorangan yang penghasilannya melebihi PTKP diharuskan mendaftarkan diri untuk memperoleh NPWP

- Wajib Pajak dapat memperoleh formulir SPT dengan cara mengambil sendiri ke KPP atau $\mathrm{KP} 2 \mathrm{KP}$, atau mengunduh melalui website www.pajak.go.id

- SPT Tahunan wajib disampaikan paling lambat 3 (tiga) bulan setelah Tahun Pajak berakhir.

- SPT Tahunan yang tidak disampaikan dalam jangka waktu yang ditetapkan atau dalam batas waktu perpanjangan penyampaian SPT Tahunan, dikenai denda sebesar Rp100.000,-.

- Penyampaian SPT Tahunan dapat dilakukan secara langsung di Kantor Pelayanan Pajak tempat Wajib Pajak terdaftar atau melalui Pojok Pajak, Mobil Pajak dan Drop Box, atau dikirimkan melalui pos, atau dengan cara lain.

- Wajib Pajak dapat memperpanjang jangka waktu penyampaian SPT Tahunan paling lama 2 (dua) bulan.

- Pemberitahuan harus disertai penghitungan sementara pajak terutang dalam 1 (satu) Tahun Pajak dan SSP sebagai bukti pelunasan kekurangan pembayaran pajak yang terutang.

Indikator variabel diukur dengan skala interval 1-5 yang diadopsi dari instrumen Palil, M. Rizal (2010) sebagai berikut : (1) : pasti salah (2). Mungkin salah (3). Tidak tahu (4). Mungkin benar (5.) pasti benar

Kepatuhan Wajib Pajak (tax compliance) Variabel Kepatuhan Wajib Pajak didefinisikan menurut Peraturan Menteri Keuangan Republik Indonesia Nomor 192/PMK.03/2007 Peraturan tersebut menyatakan bahwa wajib pajak yang memenuhi kriteria tertentu disebut sebagai wajib pajak patuh dan berhak mengajukan permohonan pengembalian pendahuluan terhadap kelebihan pembayaran pajak. Kriteria wajib pajak patuh tersebut digunakan sebagai indikator untuk mengukur variabel kepatuhan sebagai berikut :

- Menyampaikan SPT Tahunan tepat waktu dalam 3 (tiga) tahun terakhir;

- Menyampaikan SPT masa tidak melewati batas waktu penyampaian SPT masa.

- Tidak mempunyai tunggakan pajak untuk semua jenis pajak, kecuali tunggakan pajak yang telah memperoleh izin mengangsur atau menunda pembayaran pajak;

- Tidak pernah dipidana karena melakukan tindak pidana di bidang perpajakan berdasarkan putusa pengadilan yang telah mempunyai kekuatan hukum tetap dalam jangka waktu 5 (lima) tahun terakhir.

Responden diminta untuk menjawab "ya/tidak" untuk keempat pernyataan tersebut. Pengukuran variabel kepatuhan wajib pajak menggunakan variabel dummy yaitu : 1 $=$ kategori wajib pajak patuh jika responden menjawab "ya" untuk keempat pernyataan tersebut; $0=$ kategori wajib pajak tidak patuh jika ada 1 (satu) atau lebih pernyataan yang dijawab "tidak". 


\section{Populasi dan sampel}

Populasi penelitian ini yaitu wajib pajak perorangan non karyawan di kota Semarang. Kelompok wajib pajak non karyawan ditentukan sebagai populasi dalam penelitian ini karena wajib pajak perorangan non karyawan mempunyai kewajiban untuk membayar angsuran $\mathrm{PPh}$ setiap bulan. Sampel dipilih dengan metode convenience sampling. Jumlah sampel ditentukan sebesar 100 responden.

\section{Alat Analisis}

1. Deskriptif statistik

Deskriptif statistik untuk menggambarkan karakteristik responden, dan tingkat pemahaman wajib pajak terhadap peraturan perpajakan, serta tingkat kepatuhan wajib pajak.

2. Uji reliabilitas

Uji reliabilitas dilakukan pada indikator variabel pengetahuan pajak. Indikator tersebut dikatakan reliabel jika jawaban responden terhadap suatu pernyataan adalah konsisten dari waktu ke waktu. Pengukuran reliabilitas dilakukan dengan cara one shot atau pengukurannya hanya sekali kemudian hasilnya dibandingkan dengan pertanyaan laian atau mengukur korelasi jawaban antar pertanyaan.Uji reliabilitas dilakukan menggunakan software SPSS dengan uji statistik cronbach alpha. Suatu konstruk atau variabel dikatakan reliabel jika memiliki nilai cronbach alpha $>0,6$.

3. Uji validitas

Uji validitas digunakan untuk mengukur valid tidaknya kuesioner variabel pengetahuan pajak. Uji validitas pada penelitian ini dilakukan dengan melakukan korelasi bivariate antara masing-masing skor indikator dengan total skor konstruk.
2. Logistic regression untuk menguji hipotesis pengaruh pengetahuan terhadap kepatuhan wajib pajak.
a. menguji model fit
b. menguji persamaan regresi logistik

\section{Hasil Pengumpulan Data}

Responden yang berpartisipasi dalam penelitian ini meliputi wajib pajak perorangan non karyawan di seluruh kota Semarang. Berdasarkan 100 kuesioner yang diberikan kepada responden diperoleh 82 kuesioner yang terisi, sebanyak 7 kuesioner tidak terisi lengkap sehingga data tidak dapat diolah. Hasil akhir diperoleh 75 kuesioner yang dapat diolah.Statistik deskriptif dan distribusi jawaban responden sbb :

Berdasarkan hasil perhitungan diketahui bahwa untuk variabel pengetahuan nilai yang sering muncul (mode) dari jawaban responden adalah 4 (kemungkinan benar), sedangkan pertanyaan lainnya nilai yang sering muncul (mode) dari jawaban responden adalah 5. (pasti benar).

\section{Uji Validitas}

Hasil uji validitas yang ditampilkan pada tabel lampiran menunjukkan bahwa pada variabel pengetahuan pelaporan korelasi bivariate antara masing-masing skor indikator dengan total skor konstruk berkorelasi signifikan pada level 0,05

\section{Uji Reliabilitas}

1. Uji reliabilitas Variabel pengetahuan pelaporan Hasil pengujian reliabilitas pada tabel berikut ini dengan menggunakan software SPSS menunjukkan bahwa konstruk PENGETAHUAN memiliki nilai cronbach alpha 0,58 yang menurut 
kriteria Nunally (1960) dikatakan reliabel.

2. Uji reliabilitas Variabel Pengetahuan Pembayaran Pajak

Hasil pengujian reliabilitas pada tabel berikut ini dengan menggunakan software SPSS menunjukkan bahwa konstruk pengetahuan pembayaran pajak memiliki nilai cronbach alpha 0,634 yang menurut kriteria Nunally (1960) dikatakan reliabel.

3. Uji reliabilitas Variabel pengetahuan pelaporan

Hasil pengujian reliabilitas pada tabel berikut ini dengan menggunakan software SPSS menunjukkan bahwa konstruk pengetahuan pelaporan memiliki nilai cronbach alpha 0,882 yang menurut kriteria Nunally (1960) dikatakan reliabel.

\section{Uji Regresi Logistik}

a. Menilai fit model

Hipotesis untuk menilai fit model adalah :

H0 : model yang dihipotesakan fit dengan data

Ha : model yang dihipotesakan tidak fit dengan data

Hosmer and Lemeshow's goodness of fit test digunakan untuk menguji hipotesis nol. Jika nilai Hosmer and Lemeshow's goodness of fit test lebih besar dari 0,05 maka hipotesis 0 tidak dapat ditolak yang berarti model mampu memprediksi nilai observasinya.

Hosmer and Lemeshow Test

\begin{tabular}{|l|lr|rr|ll|}
\hline tep & square & Chi- & $f$ & d & ig. & S \\
\hline & 01 & 2,1 & & 7 & 954 & \\
\hline
\end{tabular}

Hasil pengujian dengan SPSS menunjukkan nilai Hosmer and Lemeshow's goodness of fit sebesar 2,101 dengan probabilitas signifikansi

0,954. Dengan demikian dapat disimpulkan bahwa model dapat diterima.

Model Summary

\begin{tabular}{|l|r|r|c|}
\hline tep & likelihood & $\begin{array}{r}\text {-2 Log } \\
\text { Snell R Square }\end{array}$ & $\begin{array}{r}\text { Nagelk } \\
\text { erke R Square }\end{array}$ \\
\hline & 67,593 &, 095 &, 150 \\
& & & \\
\hline
\end{tabular}

Nilai Nagelkerke's $\mathrm{R}^{2}$ dapat diinterpretasikan seperti nilai $\mathrm{R}^{2}$ pada multiple regression. Hasil output SPSS menunjukkan nilai Nagelkerke $\mathrm{R}^{2}$ sebesar 0,150 yang berarti variabilitas variabel dependen yang dapat dijelaskan oleh variabel independen sebesar $15 \%$. 
Tabel.1

Hasil Pengujian Persamaan Regresi Logistik

Variables in the Equation

\begin{tabular}{|c|c|c|c|c|c|c|c|c|c|}
\hline & & \multirow[t]{2}{*}{ E. } & \multirow[t]{2}{*}{ ald } & \multirow[t]{2}{*}{ df } & \multirow[t]{2}{*}{ Sig. } & \multirow[t]{2}{*}{$\operatorname{Exp}(B)$} & \multicolumn{2}{|c|}{$95 \%$ C.I.for EXP(B) } \\
\hline & & & & & & & & Lower & Upper \\
\hline \multirow{4}{*}{ Step $1^{a}$} & pelaporan & 333 & 190 & .093 & 1 & ,079 &, 716 & ,494 & 1,039 \\
\hline & pembayaran & 331 & 200 & .746 & 1 & ,097 & 1,393 & 941 & 2,061 \\
\hline & penghitungan & 049 & 066 & 557 & 1 & 455 & 1,050 & 923 & 1,195 \\
\hline & Constant & ,469 & ,758 & 432 & 1 & 511 & 11,809 & & \\
\hline
\end{tabular}

a. Variable(s) entered on step 1: pelaporan, pembayaran, penghitungan.

Hasil pengujian persamaan regressi logistik dapat dilihat pada tabel
4.5. persamaan regresi logistik dinyatakan sebagai berikut :

\section{Ln _ KEPATUHAN__ $=2,469-0,333$ pelaporan + 0,331pembayaran + ; \\ 1-KEPATUHAN 0,049penghitungan}

Variabel pelaporan pada persamaan tersebut menunjukkan adanya koefisien negatif atau arah yang berlawanan yang artinya makin tinggi pengetahuan wajib pajak tentang tata cara pelaporan pajak makin rendah tingkat kepatuhannya. Sedangkan pada variabel pengetahuan penghitungan pajak dan variabel pengetahuan pembayaran pajak menunjukkan arah koefisien positif yang artinya makin tinggi pengetahuan wajib pajak tentang cara penghitungan dan cara pembayaran pajak maka tingkat kepatuhannya juga makin tinggi.

Hasil pengujian hiptesis menunjukkan tingkat signifikansi variabel pelaporan, penghitungan, dan pem- bayaran lebih besar dari 0,05 yang artinya tidak dapat menerima $\mathrm{Ha}$ yang menyatakan ada pengaruh signifikan antara pengetahuan pelaporan, penghitungan, dan pembayaran terhadap kepatuhan.

\section{Pembahasan.}

Hasil pengujian kualitas data instrumen penelitian untuk variabel pengatahuan pelaporan, pengetahuan pembayaran pajak dan pengetahuan penghitungan pajak menunjukkan hasil yang valid dan reliabel. Namun demikian hasil uji pengaruh menunjukkan tidak ada pengaruh signifikan antara variabel pengetahuan pelaporan, pengetahuan pembayaran, 
dan pengetahuan penghitungan terhadap kepatuhan wajib pajak. Meskipun pemerintah telah menyediakan beberapa sarana yang memungkinkan wajib pajak lebih mudah dalam melaksanakan kewajibannya seperti menyediakan website yang berisi informasi peraturan pajak, call centre, bekerja sama dengan universitas dalam bentuk tax centre, dll, namun belum berpengaruh signifikan untuk meningkatkan kepatuhan wajib pajak. Hasil ini berbeda dengan penelitian-penelitian sebelumnya yang menunjukkan adanya pengaruh signikan pengetahuan terhadap kepatuhan wajib pajak. Perbedaan hasil penelitian tersebut kemungkinan terjadi karena perbedaan instrumen yang digunakan dimana pada penelitian sebelumnya yaitu Widayati dan Nurlis (2010), Nirawan Adiasa (2013) dalam mengukur variabel pengetahuan dan kepatuhan menggunakan skala likert dengan pengukuran persepsi responden yang setuju atau tidak setuju dengan pertanyaan yang diberikan. Sedangkan dalam penelitian ini untuk variabel pengetahuan responden diminta untuk menyatakan kebenaran dari pernyataan yang didasarkan pada peraturan yang saat ini berlaku. Berdasarkan data yang diperoleh menunjukkan bahwa pada instrumen PENGETAHUAN responden cenderung menjawab pada angka 5 (pasti benar) sedangkan untuk instrumen kepatuhan responden cenderung menjawab "ya" (patuh). Namun kemampuan variabel independen yaitu pengetahuan untuk mempediksi variabel dependennya yaitu kepatuhan hanya sebesar $15 \%$. Nilai tersebut kemungkinan dapat ditingkatkan dengan menambah variabel independen lain yang secara teoritis berpengaruh terhadap kepatuhan wajib pajak.

\section{Kesimpulan dan Saran}

Hasil penelitian ini menunjukkan bahwa pengetahuan wajib pajak tidak berpengaruh signifikan terhadap kepatuhan wajib pajak. Oleh karena itu disarankan sosialisasi yang diberikan oleh pemerintah sebaiknya tidak hanya memberikan pemahaman wajib pajak terhadap pelaksanaan peraturana pajak, tetapi juga memberikan informasi yang memungkinkan wajib pajak secara sukarela mematuhi kewajiban perpajakannya (voluntary compliance). Keterbatasan dan Agenda untuk Penelitian Selanjutnya.

Penelitian ini menggunakan kuesioner tertutup ddan tidak ada interaksi secara intensif dengan responden. Untuk penelitian selanjutnya perlu dilengkapi dengan wawancara intensif sehingga dapat diperoleh informasi lebih luas tentang level pengetahuan wajib pajak, hal-hal apa yang dapat meningkatkan kepatuhan wajib pajak.

Penelitian selanjutnya juga dapat menambah variabel lain yang diprediksikan dapat mempengaruhi kepatuhan wajib pajak misalnya kondisi keuangan wajib pajak.

\section{DAFTAR PUSTAKA}

Anonim, Tingkatkan Penarikan Pajak Perseorangan - Kesenjangan Masih Lebar. Kompas, 6 Maret 2014.

Anonim, Rp.150 Triliun Hilang - 40 juta Wajib Pajak Pribadi Belum Bayar Pajak. Kompas, 7 Maret 2014.

Endot Brilliantoro, 2014. Pajak Jateng : dari 1,7 WP Hanya 12\% Laksanakan Kewajiban. http://semarang.bisnis.com 
Fishbein, Martin \& Ajzen, Icek, 1975. Belief, Attitude, intention, and Behavior : An Introduction to Theory and Research. AddisonWesley Publishing Company.

Palil, Moh. Rizal, Phd. 2010. Tax Knowledge and Tax Compliance Determinants In Self Assessment System In Malaysia. Departement of Accounting and Finance Birmingham Business School, The University of Birmingham.

http://etheses.bham.ac.uk

Saad, Natrah. 2013. Tax Knowledge, Tax Complexity and Tax Compliance : Taxpayers, View. Procedia - Social and behavioral Sciences.

Tarjo \& Indra kusumawati, 2006. Analisis Perilaku Wajib Pajak Orang Pribadi terhadap Pelaksanaan Self Assessment System : Suatu Studi di Bangkalan. JAAI, Vol.10, No.1, Juni 2006.

Mardiasmo, Drs. MBA, Akt 1998. Perpajakan, Penerbit Andi, Yogyakarta.

Santoso Brotodihardjo, R.SH, 1990. Pengantar Ilmu Hukum Pajak. PT Eresco, Bandung.

Siti Resmi, 2008. Perpajakan, Teori dan Kasus, Buku 1 Edisi 4. Salemba Empat, Jakarta.

Peraturan Menteri Keuangan Republik Indonesia Nomor 192/PMK.03/ 2007 tentang Tata cara penetapan Wajib Pajak dengan kriteria tertentu dalam rangka pengembalian Pendahuluan Kelenihan Pembayaran Pajak.

Nazmel Nasir, 2010. Pengaruh Pengetahuan pajak dan Sistem Administrasi Perpajakan terhadap kepatuhan wajib pajak. (Survei atas WP-OP PBB di KPP Pratama Jakarta Pasar Rebo). Jurnal Informasi, Perpajakan, Akuntansi dan Keuangan Publik. Vol.5 No.2. Juli 2010.

Widayati, \& Nurlis, 2010. Faktor-Faktor yang Mempengaruhi Kemauan untuk membayar Pajak Wajib Pajak Orang Pribadi yang Melakukan Pekerjaan Bebas. (Studi Kasus pada KPP Pratama Gambir Tiga). Proceeding Simposium Nasional akuntansi XIII. Purwokerto 2010.

Erwin Harinurdin. 2009. Perilaku Kepatuhan Wajib Pajak Badan. Jurnal Ilmu Bisnis dan Administrasi. Vol.16 No.2. Mei-Agustus 2009.

Banu Witono, 2008. Peranan pengetahuan Pajak pada Kepatuhan Wajib Pajak. Jurnal Akuntansi dan Keuangan, Vol.7 No.2, September 2008.

Nirawan Adiasa, 2013. Pengaruh pemahaman peraturan pajak terhadap kepatuhan wajib pajak dengan moderating preferensi resiko. Accounting Analysis Journal. Agustus 2013. http://journal.unnes.ac.id/sju/ind ex.php/aaj

Margaret McKerchar, 2001. The study of income tax complexity and unintentional noncompliance : research method and 
preliminary finding ; ATAX Discussion Paper series no.6 The University of Sydney; Oktober 2001.

Marjorie E. Kornhauser. Normative and Cignitive Aspect of tax Compliance: Literature review and Recommendations for IRS Regarding Individual TaxpayerSection six;; Professor of Law Sandra Day O'Connor of College of law, Arizona state University.

James O. Alabede, Zaimah Bt. Zainol Ariffin and Kamil Md Idris. Does Taxpayer's Financial Condition Moderate determinants of tax Compliance Behavior? : Evidence from Nigeria;; British Journal of Economics, Finance, and Management Science. September 2011, Vol. 1(2)

Ojochogwu Winnie Atawodi1 \& Stephen Aanu Ojeka Factors That Affect Tax Compliance among Small and Medium

Enterprises (SMEs) in North Central Nigeria. International Journal of Business and Management Vol. 7, No. 12; June 2012 www.ccsenet.org/ijbm

James O. Alabede. Zaimah Bt. Zainol Ariffin. Kamil Md Idris Public Governance Quality and Tax Compliance Behavior in Nigeria: The Moderating Role of Financial Condition and Risk Preference_Issues in Social and Environmental Accounting. Vol. 5, No. 1/2 December 2011
Natrah Saad.2009. Fairness Perceptions and Compliance Behaviour: The Case of Salaried Taxpayers in Malaysia after Implementation of the SelfAssessment System. eJournal of Tax Research (2009) vol. 8, no. 1, pp. 32-63

Clifford g. Machogu, Dr; dr jairus b. Amayi. The effect of taxpayer education on voluntary tax Compliance, among smes in mwanza city- tanzania. International journal of marketing, financial services \& management research, Vol.2, no. 8, august (2013). www.indianresearchjournals.com 